\title{
Effect of LMP-1 and mutant P53 on the Prognosis of Undifferentiated Type of Nasopharyngeal Carcinoma
}

\author{
Atikah, Udadi Sadhana, Ika Pawitra Miranti, Dik Puspasari, Vega Karlowee \\ Department of Anatomical Pathology, Faculty of Medicine, Universitas Diponegoro, Semarang, Central Java, Indonesia \\ DATE OF ARTICLE: \\ Received: 30 Oct 2021 \\ Reviewed: 05 Nov 2021 \\ Revised: 24 Jan 2022 \\ Accepted: 28 Jan 2022 \\ CORRESPONDENCE: \\ atikah.achmadal2021@gmail.com \\ DOI: \\ 10.18196/mmjkk.v21i2.13035 \\ TYPE OF ARTICLE: \\ Research \\ Abstract: Undifferentiated carcinoma is a subtype of NPC with a higher EBV \\ antibody titer than healthy people. The carcinogenic effect of EBV involves \\ LMP-1 associated with poor prognosis, and mutant p53 predicts tumor \\ recurrence. This study aims to assess the effect of LMP-1 and mutant p53 on \\ the prognosis of NPC patients. 40 paraffin blocks were stained with LMP-1 and \\ p53 mutant. LMP-1 was positive when the cytoplasm and tumor cell \\ membranes were brown, and mutant $\mathrm{p} 53$ was positive for the brown tumor cell \\ nucleus. Pearson correlation test was performed. Most respondents were in the \\ age group $>40$ years, males, regional lymph node involvement $(\mathrm{N})$ in group $\mathrm{N} 1$, \\ and no metastasis (M). The expression levels of LMP-1 and mutant p53 were \\ strongly positive. The study showed the correlation between LMP-1 with age ( $p$ \\ $0.327)$, gender ( $p 0.599)$, category $N(p 0.512)$, category $M(p 0.019)$ and the \\ correlation between mutant $\mathrm{p} 53$ with age ( $\mathrm{p} 0.329)$, gender ( 0.981$)$, category \\ $\mathrm{N}$ ( $\mathrm{p} 0.013)$, category M (p 0.705). LMP-1 expression with mutant $\mathrm{p} 53$ ( $\mathrm{p} 0.760)$. \\ It can be concluded that LMP-1 and mutant $\mathrm{p} 53$ could be used as prognostic \\ factors in NPC patients.
}

Keywords: LMP-1; Nasopharyngeal Carcinoma; p53 Mutant; Prognosis

\section{INTRODUCTION}

Nasopharyngeal carcinoma (NPC) is the 5 th leading cause of death in Indonesia and 8th in the world. In 2020 , there were 19,943 new cases (5.0\%) in Indonesia, with a death rate of 13,399 cases (5.7\%). The incidence and death rates caused by NPC are not categorized as large, but NPC remains a concern because men with 10.7/100,000 cases dominate it compared to women with 3.00/100,000 cases. The ratio between men and women is 3-4:1. The incidence rate is $6.8 / 100,000$ cases, and the death rate is $4.7 / 100,000$ cases. ${ }^{1}$

NPC is divided into three subtypes, namely, NKSCC/NK-KNF (undifferentiated subtype and differentiated subtype), KSCC (undifferentiated and differentiated), and basaloid squamous cell carcinoma (BSCC). The second subtype is divided into differentiated and undifferentiated carcinomas. ${ }^{2-3}$ NPC's risk factors include adult males, 30-50 years old, family history of NPC, consumption of preserved foods, salted fish, smoking, and EBV infection. ${ }^{4}$ Undifferentiated carcinoma is the most common histological subtype of NPC found in Southeast Asia and Indonesia. NPC patients from various countries ranged from 4 to 91 years, with a peak incidence at 50 to 60 years in the Chinese population. ${ }^{5}$

According to the Global cancer statistics from the International Agency for Research on Cancer, there were more than 84,000 new NPC cases in 2008 , with $80 \%$ of cases in Asia and $5 \%$ in Europe. NPC is characterized by poor or undifferentiated carcinoma. NPC is endemic in South China and Southeast Asia, with an annual incidence of 15-50 cases per 100,000. Medium incidence rates of NPC are seen in Southeast Asia, including Singapore (15/100,000), Malaysia (9.7/100,000), Vietnam (7.5/100,000), Taiwan (7/100,000), and the Philippines (6.4/100,000). ${ }^{6}$ In Indonesia, with a population of 225 million people, NPC poses socio-economic problems, with an estimated overall incidence of $6.2 / 100,000$ or about 12,000 new cases per year. This disease is $100 \%$ associated with Epstein Barr virus (EBV) infection, especially the most common type of undifferentiated carcinoma WHO type III. ${ }^{5}$

Non-keratinizing squamous cell carcinoma and undifferentiated carcinoma have a higher propensity to metastasize than keratinizing squamous cell carcinoma. On the other hand, non-keratinizing squamous 
cell carcinoma and undifferentiated carcinoma have a higher degree of radiosensitivity, so they have a better prognosis. ${ }^{7}$ The treatment results in 3 years disease-free and overall survival of approximately $70 \%$ and $80 \%$, respectively. ${ }^{5}$

EBV has a carcinogenic effect through mechanisms that include latent membrane protein (LMP) consisting of LMP-1 and LMP- 2 as well as microRNA. LMP-1 is an integral protein encoded by EBV in the latent phase and is associated with poor prognosis of NPC as LMP-1 is the most influential on tumor cells growth processes such as migration, proliferation, metabolism, and tumorigenesis. ${ }^{6}$

LMP1 is expressed only on neoplastic (tumor) cells. LMP1 is expressed in most patients with premalignant lesions on the surface of their tumor tissues. ${ }^{8}$ It is the main oncogene in NPC tumorigenesis so that the expression of EBV LMP1 mRNA acts as a biological marker of latent EBV infection. ${ }^{9}$

The gene most frequently altered in human tumors is TP53 encoding the P53 protein. TP53 mutations are associated with a poor prognosis in many sporadic cancers. The primary outcome of TP53 mutations is loss of function of wild-type p53, which represents an advantage during cancer progression by eliminating intrinsic tumor suppressor's response cells, such as aging and apoptosis. Genes that make proteins are found in the nucleus of cells and play a key role in controlling cell division and cell death. Mutations (changes) in the p53 gene can cause cancer cells to grow and spread in the body. ${ }^{10}$

The $\mathrm{p} 53$ gene has been mapped to chromosome 17. Inside cells, the p53 protein binds to DNA, which stimulates other genes to produce a protein called p 21 that interacts with the cell division-stimulating protein $(\mathrm{cdk} 2) \cdot{ }^{11}$

An association between EBV infection and p53 expression was reported in idiopathic pulmonary fibrosis, gastric adenoma, gastric carcinoma, head and neck non-Hodgkin's lymphoma (NHL), Nasopharyngeal Cancer, Burkitt's Lymphoma, and Gastric Carcinoma. In addition, p53 concentrations were reported to determine cell cycle arrest and apoptosis in EBV-infected B cells. ${ }^{12}$ A positive mutant p53 expression will provide a better prognosis for the outcome of radiation therapy in NPC. NPC's prognosis with a positive mutant $\mathrm{p} 53$ expression will increase compared to a negative $\mathrm{p} 53$ mutant. ${ }^{13} \mathrm{In}$ head and neck cancer, high mutant $\mathrm{p} 53$ mutation rates have been associated with tobacco consumption and poorer prognosis. ${ }^{14}$

When mutant p53 is lost or mutant p53 is mutated, it will play a role in tumor development, progression, and chemotherapy resistance. Loss of mutant p53 also decreases apoptosis and sensitivity to radiotherapy or chemotherapy. ${ }^{15}$ Immunohistochemical studies showed that EBV infection in NPC was associated with the accumulation of mutant $\mathrm{p} 53$ protein, not with BCL-2 protein. However, other studies have concluded that $\mathrm{EBV}$ is an important etiologic factor that may involve overexpression of mutant $\mathrm{p} 53$ and $\mathrm{BCL}$ $2 .^{16}$

Overexpression of mutant p53 protein has a close relationship with the increased incidence of primary tumors and can be used as a marker for the molecular stage of head and neck malignant tumors to predict tumor recurrence and tumor response to neoadjuvant chemotherapy in head and neck malignant tumors. ${ }^{17}$ There are few studies on LMP-1 and mutant P53 in NPC available, and reports on NPC patients are inconsistent. For example, in the study of Tabyaoui et al., there was no significant correlation between the expression of LMP-1 and mutant $\mathrm{p} 53$ with histological type, age, and gender distribution shown in NPC. ${ }^{18}$

According to histologic subtype, another study explained that LMP-1 was detected in 35 NPC-positive cases, in $55 \%$ undifferentiated squamous cell carcinoma, $28 \%$ keratinized squamous cell carcinomas, and $21 \%$ in non-keratinized squamous cell carcinoma. ${ }^{19}$ Another study found that NPC cells had increased mutant p53 levels, with high LMP-1 levels correlated with higher mutant P53 expression. LMP-1 can cooperate with mutant $\mathrm{p} 53$ to induce the growth of NPC cells. ${ }^{20}$ Based on the background, the study aims to identify the effect of LMP-1 and mutant P53 on the prognosis of Nasopharyngeal Carcinoma Patient Undifferentiated Type.

\section{MATERIALS AND METHOD}

This study is an observational analytic study with a cross-sectional approach aiming to assess the immunohistochemical expression of LMP-1 and mutant p53 for the prognosis of NPC patients. This research was conducted at the Anatomical Pathology Laboratory, Dr. Kariadi Semarang.

The target population in this study were Hematoxillin Eosin (HE) slides and tissue paraffin blocks originating from the nasopharynx with NPC diagnosis. The research sample included the target population that met the inclusion and exclusion criteria. Researchers took a sample of 40 samples. The independent variables in this study were the expression of LMP1 and P53. Prognosis consisted of age, gender, regional lymph node involvement $(\mathrm{N})$, and metastases $(\mathrm{M})$ in NPC patients. 
LMP-1 immunoexpression was declared positive when the cytoplasm and tumor cell membranes were brown. The calculation of tumor cells with LMP-1 immunoexpression was viewed using a microscope with an objective lens magnification of $40 x$ by random sampling; 10 fields of view were taken. Based on distribution, 0 if no cells are positive, 1 if positive cells are $>0-1 \%, 2$ if positive cells are $>1-10 \%$, 3 if positive cells are $>10-33 \%, 4$ if the cells are positive $>33-66 \%$, and 5 . If the cells are positive $>66 \%$. By intensity: 190 if no color. 1 if color is present and intensity is weak (light brown/pale). 2 if color is present and medium intensity (brown). 3 if there is color and strong intensity (dark brown). The final score is the increase between the distribution and the intensity, namely: $0-8$, and the measuring scale is ordinal. 0 : negative, 1-2: positive weak. 3-4: medium positive. 5-8: strong positive.

Immunoexpression of p53 was declared positive when the nucleus of the tumor cells was brown. The counting of tumor cells with p53 immunoexpression was viewed using a microscope with an objective lens magnification of 40x. Random sampling took 10 fields of view. Based on distribution, 0 if no cells are positive, 1 if positive cells are $>0-1 \%, 2$ if positive cells are $>1-10 \%, 3$ if positive cells are $>10-33 \%, 4$ if the cells are positive $>33-66 \%$, and 5 If the cells are positive $>66 \%$. Based on intensity, 0 if color is none, 1 if color is present and intensity is weak (light brown/pale), 2 if color is present and medium intensity (brown), 3 if there is color and strong intensity (dark brown). The final score is the increase between the distribution and the intensity, namely: $0-8$, and the measuring scale is ordinal.35 0: negative, 1-2: positive is weak, 3-4: medium positive. 5-8: strong positive. Data processing was carried out with the help of statistical software and Microsoft Excel 2019. The correlation between LMP-1 expression and p53 expression was tested using the Pearson Correlation test. P-value $<0.05$ was considered statistically significant.

\section{RESULTS}

Characteristics of age, gender, lymph node involvement and metastases and their relationship to LMP-1 and mutant p53 in NPC patients can be seen in Table 1.

Tabel 1. Characteristics of Age, Gender, Lymph Node Involvement, Metastases, and Their Relationship to LMP-1 and Mutant P53 in NPC Patients

\begin{tabular}{|c|c|c|c|c|c|c|c|c|}
\hline \multirow{2}{*}{$\begin{array}{l}\text { Clinical } \\
\text { Parameters }\end{array}$} & \multirow{2}{*}{ Total (\%) } & \multicolumn{2}{|l|}{ LMP-1 } & \multirow{2}{*}{$\begin{array}{l}\text { P } \\
\text { (Sig.(2- } \\
\text { tailed)) }\end{array}$} & \multicolumn{3}{|c|}{ Mutant p53 } & \multirow{2}{*}{$\begin{array}{l}\mathrm{P} \\
\text { Sig.(2- } \\
\text { tailed)) }\end{array}$} \\
\hline & & $\begin{array}{l}(+) \\
\text { Positive } \\
(\%)\end{array}$ & $\begin{array}{l}(-) \\
\text { Negati } \\
\text { ve (\%) }\end{array}$ & & $\begin{array}{l}(+) \\
\text { weak } \\
(\%) \\
\end{array}$ & $\begin{array}{l}(+) \\
\text { modera } \\
\text { te }(\%)\end{array}$ & $\begin{array}{l}(+) \\
\text { strong } \\
(\%)\end{array}$ & \\
\hline Age & & & & 0.327 & & & & 0.329 \\
\hline$>46$ years old & $27(67.5 \%)$ & $27(67.5$ & 0 & & 0 & $1(2.5 \%)$ & $26(65 \%)$ & \\
\hline$\leq 46$ years old & $13(32.5 \%)$ & $\begin{array}{l}\%) \\
13(32.5 \% \\
)\end{array}$ & 0 & & $1(2.5 \%)$ & 0 & $12(30 \%)$ & \\
\hline Gender & & & & 0.599 & & & & 0.981 \\
\hline Male & $27(67.5 \%)$ & $27(67.5$ & 0 & & $1(2.5 \%)$ & 0 & $26(65 \%)$ & \\
\hline Female & $13(32.5 \%)$ & $\begin{array}{l}\%) \\
13(32.5 \% \\
)\end{array}$ & 0 & & 0 & $1(2.5 \%)$ & $12(30 \%)$ & \\
\hline Lymph nodes & & & & 0.512 & & & & $0.013^{*}$ \\
\hline No & $2(5 \%)$ & $2(5 \%)$ & 0 & & 0 & $1(2.5 \%)$ & $1(2.5 \%)$ & \\
\hline N1 & $38(95 \%)$ & $38(95 \%)$ & 0 & & $1(2.5 \%)$ & 0 & $\begin{array}{l}37(92.5 \% \\
)\end{array}$ & \\
\hline Metastasis & & & & $0.019 *$ & & & & 0.705 \\
\hline No & $3(7.5 \%)$ & $3(7.5 \%)$ & 0 & & 0 & 0 & $3(7.5 \%)$ & \\
\hline Yes & $37(92.5 \%)$ & $\begin{array}{l}37(92.5 \\
\%)\end{array}$ & 0 & & $1(2.5 \%)$ & $1(2.5 \%)$ & $35(87.5 \%$ & \\
\hline
\end{tabular}

Characteristics of the age distribution of NPC patients in this study showed 27 (67.5\%) NPC patients were > 46 years old, while $13(32.5 \%)$ NPC patients were $\leq 46$ years old. Based on these data, it was concluded that 
most NPC patients were in the age group > 46 years. Characteristics of the gender distribution of NPC patients in this study showed that $27(67.5 \%)$ were male, while 13 (32.5\%) were female. Based on these data, it was concluded that most NPC patients were male. Meanwhile, characteristics of the distribution of lymph node involvement $(\mathrm{N})$ in NPC patients in this study showed that $2(5 \%)$ NPC patients were in the No category, while 38 (95\%) NPC patients were in the N1 category. Based on these data, it was concluded that most NPC patients were included in category N1. The characteristics of the distribution of metastases in NPC patients in this study showed that 37 (92.5\%) NPC patients did not have metastases, while 3 (7.5\%) other NPC patients had metastases. Based on these data, it was concluded that most NPC patients did not have metastases. The level of expression of LMP-1 in NPC patients in this study showed that 40 (100\%) NPC patients had positive LMP-1 expression.

The results showed that 1 (2.5\%) NPC patient had a weakly positive mutant p53 expression level, 1 (2.5\%) NPC patient had a moderate positive mutant p53 expression level and $38(95 \%)$ NPC patients had a strong positive mutant p53 expression level. Based on the results of this study, it was concluded that most NPC patients had a strong positive mutant $\mathrm{p} 53$ expression level.

The results of the correlation between the expression of LMP-1 and mutant $\mathrm{p} 53$ with lymph node involvement $(\mathrm{N})$ and metastasis $(\mathrm{M})$ revealed that: 1 ) Based on the significance value of Sig. (2 tailed) between LMP-1 expression and lymph node involvement $(\mathrm{N})$, it was $0.512(>0.05)$, the calculated $r$-value was $-0.107<\mathrm{r}$ table 0.312. It can be concluded that there was no relationship between LMP-1 expression and nodes lymph involvement $(\mathrm{N}) .2$ ), Based on the significance value of Sig. (2 tailed) between LMP-1 expression and metastasis $(\mathrm{M})$, it was $0.019(<0.05)$, and the calculated $r$-value was $-0.370>\mathrm{r}$ table 0.312 . As the calculated $r$-value in this analysis is negative, indicating that the correlation between LMP-1 expression and metastasis $(M)$ is negative, it can be concluded that the higher the expression of LMP-1 is, the lower the incidence of metastasis (M) in NPC patients will be. 3) Based on the significance value of Sig. (2 tailed) between mutant p53 expression and lymph node involvement $(\mathrm{N})$, it was $0.013(<0.05), \mathrm{r}$ value $0.389>\mathrm{r}$ table 0.312 . Since the $\mathrm{r}$-count in this analysis is positive, indicating that the correlation between mutant p 53 expression and lymph node involvement $(\mathrm{N})$ is positive, it can be concluded that the higher the mutant $\mathrm{p} 53$ expression is, the more the lymph node involvement (N) in NPC patients will be. 4) Based on the significance value of Sig. (2 tailed) between mutant p53 expression and metastases $(M)$, it was $0.705(>0.05), r$ value $0.062<r$ table 0.312 ,. It can be concluded that there was no relationship between mutant p53 expression and metastasis (M). LMP-1 expression in nasopharyngeal tissue of nasopharyngeal carcinoma patients can be seen in Figures 1 and 2.
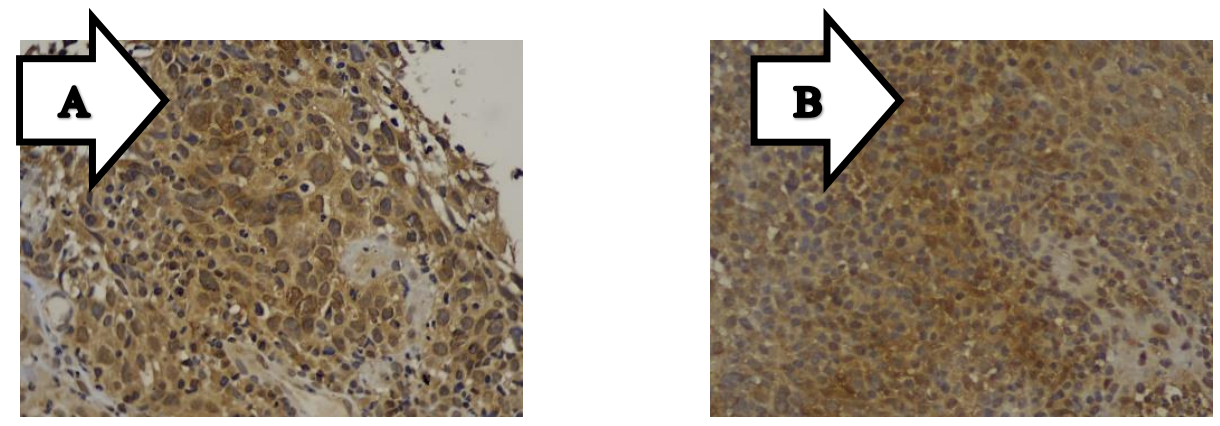

Figure 1. LMP-1 medium expression (A). LMP-1 strong expression (B).
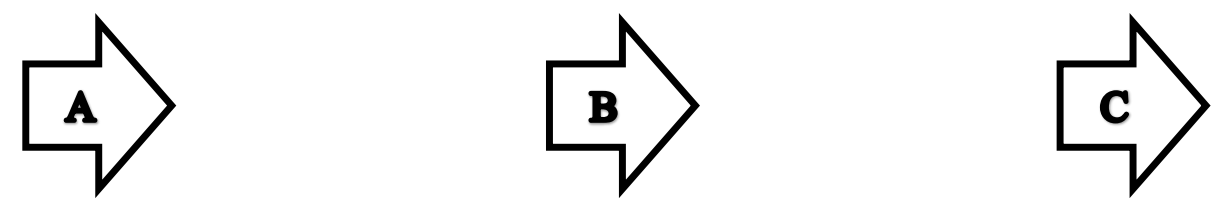

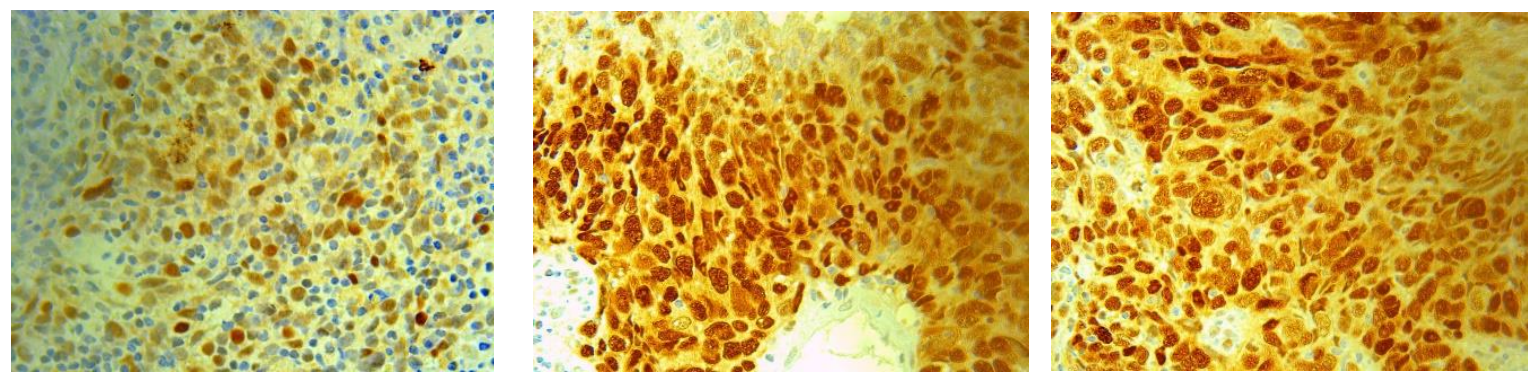

Figure 2. Mutant p53 week expression (A). Mutant p53 medium expression (B). Mutant p53 strong expression (C).

\section{DISCUSSION}

\section{Patient age distribution}

The results of this study are in line with research conducted by Dawolo, which stated that most nasopharyngeal cancer patients were in the age group 46-55 years (30.91\%). ${ }^{22}$ The similar aspect was also explained by Barns that in areas with a high risk of nasopharyngeal cancer, the incidence increased after the age of 30 and peaked at the age of $40-60$ years. ${ }^{23}$

Furthermore, the results of this study are in accordance with the study conducted by Fatusi et al. explaining that NPC patients from various countries can suffer from ages from 4 to 91 years, with a peak incidence at 50 to 60 years in the Chinese population. Generally, NPC is rare in individuals under 20 years old (less than 1\%), whereas a bimodal age distribution has been described in northern Africa, with $20 \%$ of patients under 30 years of age. ${ }^{24}$

Another study by Chang YL also showed similar results to our study where 323 new patients were treated between 1998 and 2004 at the National University Hospital in Singapore; 36\% to 40\% were diagnosed at the age of 41 to 50 years. According to the literature, the overall incidence peaks at 50 to 60 years of age. In highrisk areas such as Hong Kong, the incidence of NPC in each gender increases sharply from 20 years and above and peaks between 40 and 60 years. ${ }^{25}$

Another study by Barnes also explained that age is also a risk factor for nasopharyngeal cancer. The incidence of nasopharyngeal cancer increases after the age of 30 and peaks at the age of 40-60 years. After the age of 60 , the incidence begins to decline. Meanwhile, another study by Tsao also revealed that the incidence of nasopharyngeal cancer commonly occurred at the age of 45 to 54 years. ${ }^{26}$

Guo et al. also stated that the incidence of nasopharyngeal cancer began to increase after the age of 30 years; $93 \%$ occurred after passing the age of 30 years, with the highest peak at the age of 45-55 years. The study results found a significant reduction in the incidence of nasopharyngeal cancer in the age group $>65$ years. It is in line with research stating that the incidence began to decline after the age of $60 .{ }^{27}$

Kumar et al. explained that nasopharyngeal cancer is mostly found in productive ages, especially at the age of 46-55 years, as cancer growth takes a long time. The increasing incidence of cancer at this age can be explained by the accumulation of somatic mutations associated with cancer. Decreased immune system resistance due to age is a factor that may increase the risk of cancer. ${ }^{28}$

\section{Gender distribution}

The research by Ismail and Savitri at the Dr. Central General Hospital Wahidin Sudirohusodo and Hasanuddin University Hospital revealed that male NPC patients had a higher percentage than females. The Central General Hospital, Dr. Wahidin Sudirohusodo, found as many as $64.18 \%$ of male patients, while patients with female gender were $35.82 \%$. Meanwhile, at Hasanuddin University Hospital, $55.56 \%$ of NPC patients were male, and $44.44 \%$ were female. ${ }^{29}$ IARC states that men are more likely to experience NPC of $72.73 \% .{ }^{29}$ It is also stated that men had a higher risk of developing NPC than women, about 2-3 times higher. GLOBOCAN also states that men had 1.38 times higher risk of developing nasopharyngeal cancer than women. ${ }^{30}$

Xie et al. concluded that the incidence rate of NPC across populations was male predominance. In most populations, NPC's male to female incidence ratio is approximately 2-3:1.31 Sulaksana et al. denoted that the number of male respondents was greater than female respondents with a ratio of 2.5:1. These results are 
consistent with many previous studies reporting that NPC is more common in men than women, with a 2-3:1 ratio. ${ }^{32}$ Xie et al. explained that the male predominance in NPC incidence could be partly explained by differences in the prevalence of several environmental risk factors, such as smoking and occupational exposure to hazardous. It is also possible that some intrinsic exposures, such as sex hormones, may explain the observed male predominance of the protective effects of endogenous estrogens. ${ }^{31}$ Another study by Utama also explained that NPC is influenced by gender. It occurred since some of the most common factors that cause NPC are often found in men, such as smoking, drinking alcohol, and exposure to wood dust. ${ }^{33}$

\section{Distribution of regional lymph node involvement $(\mathrm{N})$}

The results of this study were different from other studies by Utama, which concluded that based on the description of cervical lymph node metastases, the most common result was lymph nodes in the N3 group of 7 patients (58.3\%). Furthermore, the most N1 lymph nodes were 3 patients (25\%), while No and N2 were 1 patient $(8.33 \%) .33$

Licitra explained that the neck lymph nodes that are painless and grow slowly often make the patient ignore complaints. Therefore, patients carried out medical checks up when they were already in an advanced stage. ${ }^{34}$

\section{Distribution of distant metastases (M)}

This study differed from other studies by Zheng, who explained that the incidence of metastases was much higher in locally advanced NPC, and the most common sites were bone, lung, and liver. ${ }^{35}$ According to Brennan, NPC usually originates from the lateral wall of the nasopharynx, which includes the fossa of Rosenmuller. They may extend into or out of the nasopharynx to other lateral walls and posterosuperior to the skull base or palate, nasal cavity, or oropharynx, then usually metastasizes to the glands neck lymph. Distant metastases can occur in bone, lung, mediastinum, and less commonly, the liver. ${ }^{36}$

Another study by Bensouda et al. concluded that metastases were found in only 5 to $7 \%$ of patients at initial diagnosis. These are mainly metachronous metastases found in evolution, usually within 3 years of treatment. The overall rate of metastasis is $25-30 \%$. The occurrence of metastases is associated with the primary tumor $(\mathrm{T})$, especially for lymph node involvement $(\mathrm{N})$, and is most common in $\mathrm{T}_{3}-\mathrm{T}_{4}$ or $\mathrm{N} 2-\mathrm{N} 3$ tumors. The most frequent sites of metastases were bone (70-80\%), followed by liver 30\%, lungs, $18 \%$ ), and, to a lesser extent, extra-cervical lymph nodes (axillary, mediastinal, pelvic, inguinal). Prognosis depends on location: hepatic and medullary involvement has a poor prognosis, while isolated bone metastases may be associated with prolonged survival. ${ }^{37}$

\section{LMP-1 expression results}

These results illustrate that EBV infection is the biggest risk factor in this NPC case, just like other endemic areas. Based on the literature by Khabir A et al., it was found that LMP-1 was frequently detected on NPC biopsy but with wide variation among tumors. Based on most reports from various parts of the world, approximately $50 \%-60 \%$ of NPC biopsies, LMP-1, can be visualized in most tumor cells using immunohistochemical techniques. LMP-1, which is highly expressed in NPC specimens, is thought to play a role not only in oncogenesis but also in maintaining the latent nature of the virus..$^{38}$

The results of this study are in accordance with the study conducted by Hau et al., showing that increased LMP1 expression in NPC cells was associated with Id1 overexpression. Id1 (inhibitor of differentiation-1) is an activator of the -cell proliferation process. ${ }^{39}$ Another study by Zheng et al. explained that LMP1 is an integral membrane protein containing a cytoplasmic amino terminus, six transmembrane domains, and a long cytoplasmic carboxy-terminal portion. LMP1 functions as a tumor necrosis factor receptor (TNFR) surrogate, activating several signaling pathways. LMP1 is functionally similar to $C D 40$, a member of the tumor necrosis factor receptor superfamily, giving rise to B cell growth and differentiation signals. Two functional domains, namely C-terminal activation regions-1 (CTAR-1) and CTAR-2, in the cytoplasmic carboxyl terminus of LMP1, can activate the transcription factor NF-kB, which can lead to upregulation of antiapoptotic gene products. LMP1 plays an important role in the immortality of human B cells by activating some cellular signaling pathways, including NF-kB, JNK, JAK/STAT, P38/MAP, and Ras/MAPK. LMP1 alters several functional materials involved in tumor progression and invasion in human nasopharyngeal epithelial cells. The findings in this study indicated that LMP1 increased the transcription and expression of MMP-9 through NF-kB and AP-1, which was one of the mechanisms of LMP1 in mediating the invasion and metastasis of NPC cells. In addition, LMP1 also increased VEGF transcription and expression in NPC cell lines through the JAK3/STAT3 pathway. LMP2 was not involved in B cell transformation in vitro, but its expression showed an important role in 
maintaining the virus in the body. In this study, it was stated that LMP1 is the main molecule in the pathogenesis of NPC; thus, disrupting LMP1 signaling becomes a promising strategy for targeted therapy in NPC. 40

Gullo et al. explained that EBV-encoded latent membrane proteins; LMP1 is an integral membrane protein with oncogenic potential, encoded by the BNLF-1 gene (also known as the LMP1 gene) EBV. It can transform rodent cells and alter the phenotype of both lymphoid and epithelial cells. LMP1 is expressed in most NPC and is strongly suspected of having an important role in the pathogenesis and development of NPC, and its expression is associated with poor prognosis. ${ }^{41}$ Linct et al. concluded that EBV has morphological properties (bound only) to nasopharyngeal epithelial and lymphocytes. The expression of LMP1 in carcinoma cells indicated that the origin of these cells came from the nasopharynx. ${ }^{42}$

\section{The $\mathrm{p} 53$ expression results}

Another study by Sheu et al. also detected $95 \%$ of the mutant p 53 protein in the nucleus of tumor cells. ${ }^{43}$ Similar results were also obtained in another study by Suharto and Harijadi, which stated that mutant p53 expression was positive in $89.8 \%$ of NPC cases. ${ }^{44}$ Research by Taweevisit in Bangkok on 60 cases of NPC found that there was an overexpression of mutant p 53 protein in $73 \%$ of cases. It indicated that the mutant p53 protein is closely related to NPC tumorigenesis. Most of the NPC showed mutant p53 overexpression, and the majority of these mutant $\mathrm{p} 53$ were wild-type mutant $\mathrm{p} 53$ (normal) which might be a response to EBV infection. The overexpression of mutant $\mathrm{p} 53$ in NPC is not caused by mutant p53 protein. ${ }^{4}$

This study is in line with the research results by Agaoglu et al., which argued that the immunohistochemistrydefined overexpression of mutant p53 was high. An overall immunoreactivity rate of $95 \%$ with strong immunoreactivity $(>10 \%)$ in $65 \%$ of patients has been reported in Chinese patients. Among the total 97 samples, positive staining for mutant p53 protein was observed in $83(85.5 \%)$ samples, while no staining was found in $14(14.5 \%)$ cases. Immunoreactivity was observed in $62(81.5 \%)$ primary nasopharyngeal biopsy specimens. ${ }^{14}$ Zhang et al. explained that the mutant p53 pathway is one of the most important pathways regulating the cell cycle. Mutant p53 is activated in response to various internal and external stresses and increases the transcription factor p21 and its translation products. p21 induces G1 cell cycle arrest and DNA repair by inhibiting cyclin-dependent kinase- 5 and increasing the expression of inducible growth arrest and DNA damage genes. When DNA damage is irreparable, mutant $\mathrm{p} 53$ induces apoptosis by increasing $\mathrm{Bcl}-2$ associated protein X (BAX) expression and the formation of BAX homodimers. Mutations in the mutant P53 gene are among the most common genetic changes in human tumors. Approximately $50 \%$ of human tumors exhibit mutant p53 mutations. ${ }^{46}$

Furthermore, Sheu et al. concluded that the mutant p53 protein is closely related to NPC incidence. In most NPC studies, an increase in mutant p53 expression was found, and generally normal ("wild") mutant p53 was probably a reaction to Epstein-Barr virus infection because only 10\% of NPCs had mutations in their mutant P53 protein. ${ }^{43}$ Tejosukmono and Suharto explained that mutant p53 is thought to regulate the arrangement or function of the DNA replication-initiation complex. In the SV4O DNA replication-initiation process, the T antigen acts as a helicase to promote replication and binds to the DNA polymerase required to synthesize the SV 40 DNA. The mutant $\mathrm{P} 53$ protein can bind to the T antigen so that the activity of the $T$ antigen as a helicase is inhibited. Moreover, there was no binding to DNA polymerase, so DNA synthesis did not occur. In cells that do not contain the SV40 virus or do not contain the T antigen, the mutant p53 protein binds to other compounds that are homologous to the T antigen. ${ }^{13}$

Another study by Lee et al. denoted that the stability and activation of mutant p53 and its transcriptional targets are critical for determining malignancy development or aversion. An important protein in regulating mutant $\mathrm{p} 53$ is MDM2, where MDM2 controls mutant $\mathrm{p} 53$ levels under non-stress conditions. The interaction between mutant $\mathrm{p} 53$ and MDM2 causes mutant $\mathrm{p} 53$ to be spread everywhere and eventually degraded; thus, blocking the interaction allows mutant $\mathrm{p} 53$ to be activated when a voltage is detected. One commonly used drug developed for this affinity is nutlin-3, widely used in cancer studies. The activation of the mutant p53 pathway has been described to induce cell cycle arrest or apoptosis via transcriptional targets such as p21 and Bax21. It suggests that not all mRNAs are equally translated into proteins as the regulation of transcription and translation varies under different conditions. ${ }^{47}$

In addition, Agaoglu et al. revealed that in head and neck cancer, high mutant p53 mutation rates were associated with tobacco consumption and poorer prognosis. Although point mutations in the mutant p53 gene were observed in nasopharyngeal cancer, the mutation rate was lower than in other tumors. On the other hand, mutant p 53 can be easily detected with an extended half-life. Immunohistochemical studies have demonstrated significant overexpression of mutant P53 in NPC. ${ }^{14}$ 
Correlation between LMP-1 expression with regional lymph node involvement $(\mathrm{N})$

The results of this study align with other studies by Adam et al., revealing there was no significant relationship between LMP-1 expression with regional lymph nodes $(\mathrm{N})$ with $\mathrm{p} 0.553 .{ }^{15}$ In another study by Poida et al. in the Department of Anatomical Pathology, Faculty of Medicine, University of North Sumatra, 28 patients (82.4\%) had lymph node diameters less than $6 \mathrm{~cm}$, while 6 patients $(17.6 \%)$ had different results. NPC patients with single lymph node enlargement were obtained as many as 25 people $(73.5 \%)$ while those with multiple lymph node enlargements were 9 people (26.5\%)..$^{48}$

\section{Correlation between LMP-1 expression with distant metastases (M)}

The results of this study showed that there was a negative correlation between the expression of LMP-1 with distant metastases $(M)$ with the value of Sig. $(2$ tailed $)=0.019(>0.05)$, $r$ count $-0.370>r$ table 0.312 . It can be concluded that the higher the expression of LMP-1, the lower the incidence of distant metastases (M) in NPC patients. The results of this study are in line with research by Sarac et al., which concluded that there was a significant relationship between LMP-1 expression and distant metastases (M) tumors with p $0.04^{49}$

Nakanishi et al. explained that the most common clinical symptom of NPC is the presence of cervical lymph node metastases represented as a neck mass. The first evidence for the relevance of LMP-1 regarding the metastatic properties of NPC is that LMP-1 induces matrix metalloproteinase (MMP)-9. While some studies have identified a positive correlation between LMP-1 expression and NPC metastatic status, other studies have failed to identify the link. These conflicting results may be due to the sample size and the method used to evaluate LMP-1. Furthermore, LMP-1 was shown to downregulate cell-cell adhesion and upregulate cell motility through its-1 and c-Met activation and ezrin expression. LMP-1 has also been shown to induce the expression of Mucin-1 (MUC-1), which plays an important role in tumor invasion and metastasis by countering cell adhesion. ${ }^{50}$

\section{Correlation between p53 and lymph node involvement $(\mathrm{N})$}

The results of this study are in line with other studies by Zhang et al. explained that the expression level of mutant p53 was significantly higher in NPC patients with lymph node metastases than those without lymph node metastases with $\mathrm{p} 0.001 .^{46}$

Another study by Chow et al. explained that patients with high mutant p53 expression had significantly higher lymph node counts. ${ }^{11}$ Another study by Aswarin et al. obtained different results showing no relationship between mutant p53 expression from metastatic lymph nodes in NPC. The results of the Mann-Whitney $U$ test were $p 0.706$, so there was no significant relationship $(p>0.05)$ between the positive expression of mutant p53 protein in NPC and regional lymph nodes, namely No, N1, N2, and N3. There was no significant difference between regional mutant $\mathrm{p} 53$ protein expression and lymph nodes in NPC. According to research, the greatest role of mutant p53 protein expression has been started early in tumor development, before the occurrence of spread to lymph nodes and distant metastases. In tumors with distant metastases, the mutant p53 protein's expression is small. Proteins that play a role in cell cycle control are suppressor genes and tumor oncogenes. The role of the mutant p53 protein in cell cycle regulation is to inhibit cell division, where the mutant p53 protein will trigger the p21 transcription process. An increase in p21 will cause the mutant p53 protein to inhibit all CDKs, while a non-functioning CDK will impact cyclins not to form complexes with CDKs; this affects the cell cycle stops. By triggering the cell division cycle again, the causative factor is the MDM-2 protein. The activity of this protein will suppress the activity of the mutant p53 protein. The low activity of the mutant p53 protein resulted in a decrease in p21 expression as a result that CDK was not inhibited so that a cycle would form a complex with CDK. The complex binding between CDK-cyclin will cause the cell cycle to continue. If a mutant p53 protein mutation occurs, the resulting protein is inactive and cannot trigger the formation of p21. Low p21 expression resulted in uninhibited CDK, and the cell division cycle continued. On the other hand, mutations in the mutant p53 protein result in the impaired activity of the BAX protein so that the pores in the mitochondrial membrane cannot open, and ultimately the cell does not undergo apoptosis. ${ }^{52}$

\section{Correlation between p53 expression and the incidence of distant metastases (M)}

The results of this study are different from other studies by Sawali et al., stating that NPC had a higher risk of distant metastases than other malignant head and neck tumors. With lymph node involvement, the high proliferation rate may explain its tendency to develop distant metastases. The incidence of isolated distant metastases is high, globally at $18 \%$, and the risk increases with disease stage ( $47 \%$ for stage IVB), suggesting that locoregional treatment alone for locally advanced stages of the disease is inadequate. The lungs are the most common site of metastases, followed by bone and liver. 53 


\section{Correlation between LMP-1 expression and p53 expression}

The results of this study contradict another study by Shao et al., who explained that the accumulation of mutant P53 in NPC was significantly correlated with LMP-1 overexpression. ${ }^{54}$ Another study by Chou et al. showed that NPC cells had increased mutant p53 levels, and high levels of LMP-1 correlated with higher mutant P53 expression. ${ }^{55}$ Lubis explained that LMP-1 inhibited the suppression effect of wild-type mutant p53, so tumor growth and progression occurred. LMP-1 was also able to defeat growth inhibition stimulated by wild-type p 53 mutant. In addition, LMP-1 could cooperate with mutant p 53 to induce the growth of NPC cells. ${ }^{56}$

\section{Differences between LMP-1 expression and p53 expression}

The results of this study are in line with other studies by Shao et al., who explained that Immunohistochemical analysis of NPC specimens showed a positive correlation between LMP-1 expression and mutant p53 expression. 54 The results obtained indicated that the accumulation of mutant p53 in NPC was significantly correlated with LMP-1 overexpression. This study obtained the same results as the theory from the existing literature, namely NPC cells had increased mutant $\mathrm{p} 53$ levels and high levels of LMP-1 correlated with higher mutant $\mathrm{p} 53$ expression. LMP-1 inhibited the suppression effect of wild-type mutant $\mathrm{p} 53$, so tumor growth and progression occurred. LMP-1 was also able to defeat growth inhibition stimulated by wild-type p53 mutant. In addition, LMP-1 could cooperate with mutant p53 to induce the growth of NPC cells. ${ }^{56}$

The results of this study are different from the research by Asri $A$, denoting that there was a weak correlation between LMP-1 expression and mutant p53 expression ( $r$ 0.249) that had a positive pattern. Based on the results of statistical tests, there was a non-significant relationship between the expression of LMP-1 and the expression of mutant $\mathrm{p} 53$ ( $\mathrm{p}$ 0.085).57

\section{CONCLUSION}

The expression levels of LMP-1 and mutant $\mathrm{p} 53$ were positive in NPC, especially in non-keratinizing carcinoma, undifferentiated type. Distant metastasis correlated with LMP-1, whereas lymph node involvement correlated with P53 mutant. Meanwhile, age and gender did not correlate with LMP-1 and mutant p53.

The results indicated that LMP-1 and mutant $\mathrm{p} 53$ expression could be used as determining factors in NPC prognosis and could be proposed as an alternative in the treatment of NPC by administering an LMP-1 inhibitor and mutant p53 as neoadjuvant chemotherapy.

\section{CONFLICT OF INTEREST}

There is no conflict of interest in this research.

\section{REFERENCES}

1. Ferlay J, Ervik M, Lam F, Colombet M, Mery L, Piñeros M. International Agency for Research on Cancer 2020. Glob Cancer Obs Cancer 2020;419:1-2. https://gco.iarc.fr/today/data/factsheets/populations/900-world-fact-sheets.pdf.

2. El-Naggar AK, Chan JKC, Grandis JR, Takata T SP. IARC Publications Website - WHO Classification of Head and Neck Tumours. 2017. https://publications.iarc.fr/Book-And-Report-Series/Who-ClassificationOf-Tumours/WHO-Classification-Of-Head-And-Neck-Tumours-2017\%0Ahttp://publications.iarc.fr/BookAnd-Report-Series/Who-Iarc-Classification-Of-Tumours.

3. Tabuchi K, Nakayama M, Nishimura B, Hayashi K, Hara A. Early Detection of Nasopharyngeal Carcinoma. Int J Otolaryngol. 2011;2011. https://doi.org/10.1155/2011/638058

4. Zeng M-S, Zeng Y-X. Pathogenesis and Etiology of Nasopharyngeal Carcinoma. 2010:9-25. doi:10.1007/9783-540-92810-2_2

5. Adham M, Kurniawan AN, Muhtadi AI, Roezin A, Hermani B, Gondhowiarjo S, Tan IB, Middeldorp JM. Nasopharyngeal Carcinoma in Indonesia: Epidemiology, Incidence, Signs, and Symptoms at Presentation. Chin J Cancer. 2012;31(4):185-196. https://doi.org/10.5732/cjc.011.10328

6. Zhang L, Chen QY, Liu H, Tang LQ, Mai HQ. Emerging Treatment Options for Nasopharyngeal Carcinoma. Drug Des Devel Ther. 2013;7:37-52. https://doi.org/10.2147/DDDT.S30753 


\section{mutiara medika}

7. Xu T, Tang J, Gu M, Liu L, Wei W, Yang H. Recurrent Nasopharyngeal Carcinoma: A Clinical Dilemma and Challenge. Curr Oncol. 2013; 20(5): e406-19. https://doi.org/10.3747/co.20.1456

8. Nawandar DM, Makoto Ohashi, Reza Djavadian, Elizabeth Barlow A, Kathleen Makielski, Ahmed Ali, Denis Lee, Paul F. Lambert, Eric Johannsen C, Shannon C. Kenneya C. Differentiation-Dependent LMP1 Expression Is Required for Efficient Lytic Epstein-Barr Virus Reactivation in Epithelial Cells. J Virol. 2017;91(8):1-18. https://doi.org/10.1128/JVI.02438-16

9. Wahyono DJ, Widikusumo A, Sulistyo H. Ekspresi Relatif mRNA LMP1 Epstein-Barr Virus dari Jaringan Tumor Terfiksasi Formalin dalam Blok Parafin sebagai Biomarker Progresivitas Tumor pada Karsinoma Nasofaring Tidak Berdiferensiasi. J Biotek Medisiana Indo. 8(1):43-50. https://doi.org/10.22435/jbmi.v8i1.2582

10. Mantovani F, Collavin L, Del Sal G. Mutant p53 as a guardian of the cancer cell. Cell Death Differ. 2019;26(2):199-212. https://doi.org/10.1038/s41418-018-0246-9

11. National Center for Biotechnology Information (US). The p53 Tumor Suppressor Protein. 1998; (Md): $346-$ 355. https://www.ncbi.nlm.nih.gov/books/NBK22268/.

12. Chatterjee K, Das P, Chattopadhyay NR, Mal S, Choudhuri T. The Interplay between Epstein-Bar virus (EBV) with the p53 and Its Homologs during EBV Associated Malignancies. Heliyon. 2019; 5(11):e02624. https://doi.org/10.1016/j.heliyon.2019.e02624

13. Tejosukmono A, Suharto A. Hubungan Ekspresi p53 dengan Prognosis Hasil Terapi Radiasi pada Karsinoma Nasofaring Relation p53 Expression and Prognosis of Radiation Therapy in Nasopharyngeal Carcinoma. Mutiara Medika: Jurnal Kedokteran dan Kesehatan. 2012;12(3):133-137. https://doi.org/10.18196/mmjkk.v12i3.1029

14. Agaoglu FY, Dizdar Y, Dogan O, Alatli C, Ayan I, Savci N. P53 Overexpression in Nasopharyngeal Carcinoma. In Vivo (Brooklyn). 2004;18(5):555-560.

15. Fachiroh J, Schouten T, Hariwiyanto B, Paramita DK, Harijadi A, Haryana SM, \& Middeldorp JM. (2004). Molecular Diversity of Epstein-Barr Virus IgG and IgA Antibody Responses in Nasopharyngeal Carcinoma: a Comparison of Indonesian, Chinese, and European Subjects. The Journal of Infectious Diseases, 53-62.

16. Lee AWM, Ma BBY, Ng WT, Chan ATC. Management of Nasopharyngeal Carcinoma : Current Practice and Future Management of Nasopharyngeal Carcinoma: Current Practice and Future Perspective. 2015;3356-64. https://doi.org/10.1200/JCO.2015.60.9347

17. Poh Y, Gan SY, Tan E. Effects of IL-6, IL-10 and TGF- $\beta$ on the Expression of Survivin and Apoptosis in Nasopharyngeal Carcinoma TW01 Cells. 2012:34(2): 85-9.

18. Tabyaoui I, Serhier Z, Sahraoui S, Sayd S, Cadi R, Bennani OM. Immunohistochemical Expression of Latent Membrane Protein 1 ( LMP1) and p53 in Nasopharyngeal Carcinoma: Moroccan Experience. 2013;13(3):710-717. https://doi.org/10.4314/ahs.v13i3.27

19. Elemam IBY, Yousif M, Mohammed Y, and Elaziz SA. Immunohistochemical Expression of Latent Membrane Protein-1 (Lmp-1) Among Sudanese Patients with Nasopharyngeal Carcinoma. Int J Res Granthaalayah. 2015;3(9):101-107. https://doi.org/10.29121/granthaalayah.v3.i9.2015.2950

20. Singh P. Sample Size for Experimental Studies. J Clin Prev Cardiol. 2012;(2):88-93.

21. Stenmark MH, Mchugh JB, Schipper M, Walline HM, Komarck C, Feng FY, et al. Nonendemic HPV-Positive Nasopharyngeal Carcinoma: Association with Poor Prognosis. Int J Radiat Oncol Biol Phys. 2014; 88(3): 580588. https://doi.org/10.1016/j.ijrobp.2013.11.246

22. Dawolo AP, Utama DS, and Kasim BI. Profil Klinis Karsinoma Nasofaring di Departemen THTKL RSUP Dr. Mohammad Hoesin Palembang Tahun 2014-2015. Maj Kedokt Sriwij. 2019;49(1):1-9.

23. Barnes L, Eveson JW, Reichart P, and Sidransky D. World Health Organization Classification of Tumours Pathology \& Genetics Head and Neck Tumours IARC WHO Classification Head and Neck Tumours.

24. Fatusi $\mathrm{O}$, Akinpelu $\mathrm{O}$, and Amusa Y. Challenges of Managing Nasopharyngeal Carcinoma in a Developing Country. J Natl Med Assoc. 2006;98(5):758-764.

25. Chang YL. Nasopharyngeal Carcinoma in Taiwan. J Formos Med Assoc. 1992;91 Suppl 1:362-368.

26. Tsao SW, Yip YL, Tsang CM, Pang PS, Lau VMY, and Lo GZKW. Etiological Factors of Nasopharyngeal Carcinoma. Oral Oncol. 2014;50(5):330-338.

27. Guo X, Johnson RC, Deng H, Liao J, Guan LGW, Nelson. Evaluation of Non-viral Risk Factors for Nasopharyngeal Carcinoma in a High-risk Population of Southern China. Int J Cancer. 2009;124(12):29422947.

28. Kumar V, Abul K, Abbas JCA. Robbins Pathologic Basis of Disease.; 10th Edition, 2018, Elsevier, Philadelphia, USA. 
29. Ismail AF, dan Savitri E. Karakteristik Pasien Karsinoma Nasofaring di Rumah Sakit Umum Pusat Dr. Wahidin Sudirohusodo dan Rumah Sakit Universitas Hasanuddin Periode Tahun 2012 - 2016. Skripsi. FK Univ Hasanudin. 2017.

30. International Agency for Research on Cancer (IARC). Indonesia - Global Cancer Observatory. Globocan. 2020;858:1-2.

31. Xie SH, Yu ITS, Tse LA, Mang OWK, Yue L. Sex Difference in the Incidence of Nasopharyngeal Carcinoma in Hong Kong 1983-2008: Suggestion of a Potential Protective Role of Oestrogen. Eur J Cancer. 2013;49(1):150-155. https://doi.org/10.1016/j.ejca.2012.07.004

32. Sulaksana MA, Kadriyan H. Characteristics and Risk Factors of Patients with Nasopharyngeal Carcinoma in West Nusa Tenggara Hospital. Int J Nasopharyngeal Carcinoma. 2019;1(03):83-85. https://doi.org/10.32734/ijnpc.v1i03.2058

33. Utama DS. The Characteristics of Adolescents Nasopharyngeal Carcinoma Patients in Mohammad Hoesin General Hospital Palembang January 2013-December 2017. 2019;01(01):2017-2019. https://doi.org/10.32734/ijnpc.v1i1.955

34. Licitra L, Felip E, Chan ATC, Gre V. Clinical Practice Guidelines Nasopharyngeal Cancer : EHNS - ESMO - ESTRO Clinical Clinical Practice Guidelines. 2010; 21 (Supplement 5): 187-189. https://doi.org/10.1093/annonc/mdq186

35. Zeng Y, Chen H, Xiang Z, Liu F, and Liu L. Case Report Nasopharyngeal Carcinoma with Metastasis to the Central Nervous System : a Report of Two Patients and Review of the Literature. 2019;12(11):4142-4149.

36. Brennan B. Nasopharyngeal Carcinoma. 2006;5:1-5. https://doi.org/10.1186/1750-1172-1-23

37. Bensouda Y, Kaikani W, Ahbeddou N, Rahhali R, Jabri M, Mrabti H. Treatment for, Metastatic Nasopharyngeal Carcinoma. Eur Ann Otorhinolaryngol Head Neck Dis. 2011;128(2):79-85. https://doi.org/10.1016/j.anorl.2010.10.003

38. Khabir A, Karray H, Rodriguez S, Rose M, Daoud J, Frikha M. EBV Latent Membrane Protein 1 Abundance Correlates with Patient Age but not with Metastatic Behavior in North African Nasopharyngeal Carcinomas. 7:1-7. https://doi.org/10.1186/1743-422X-2-39

39. Hau PM, Tsang CM, Yip YL, Huen MSY, Tsao SW. Id1 Interacts and Stabilizes the Epstein-Barr Virus Latent Membrane Protein 1 (LMP1) in Nasopharyngeal Epithelial Cells. PLoS ONE, 2011;6(6):1-10. https://doi.org/10.1371/journal.pone.0021176

40. Zheng H, Li L, Hu D, Deng X, Cao Y. Role of Epstein-Barr Virus Encoded Latent Membrane Protein 1 in the Carcinogenesis of Nasopharyngeal Carcinoma. Cell Mol Immunol. 2007 Jun;4(3):185-96.

41. Gullo C, Low WK, Teoh G. Association of Epstein-Barr Virus with Nasopharyngeal Carcinoma and Current Status of Development of Cancer-derived Cell Lines. Ann Acad Med Singap. 2008 Sep;37(9):769-77.

42. Lin C-T. Relationship between Epstein-Barr Virus Infection and Nasopharyngeal Carcinoma Pathogenesis. Chin J Cancer. 2009;28(8):1-14. https://doi.org/10.5732/cjc.009.10107

43. Lai-fa Sheu, Ann Chen, Hui-Hwa Tseng, Fur-Jiang Leu, John K Lin K-CHC-LM. Assessment of p53 Expression in Nasopharyngeal Carcinoma. Hum Pathol. 1995;26(4):380-386.

44. Agus S, Harijadi. Ekspresi p53 dan p21 waf/cip-1 pada Karsinoma Nasofaring. Maj Patol Indones. 2004;13:86-91.

45. Taweevisit M. Overexpression of p53 and Neoplastic Cell Proliferation in Undifferentiated Nasopharyngeal Carcinoma. Southeast Asian J Trop Med Public Heal. 2007;38(1):136-140.

46. Zhang P, Wu SKE, Wang Y. p53, MDM2, eIF4E and EGFR Expression in Nasopharyngeal Carcinoma and their Correlation with Clinicopathological Characteristics and Prognosis : A retrospective Study. 2015:113. 118. https://doi.org/10.3892/ol.2014.2631

47. Lee BK, Linton RE, and Nissom PM. Investigating the Influence of Epstein-Barr Virus on the p53 Pathway in Nasopharyngeal Carcinoma Investigating the Influence of Epstein-Barr Virus on the p53 Pathway in Nasopharyngeal Carcinoma. 2019:0-8. https:// 10.1088/1742-6596/1175/1/012078

48. Gurning PPB, Nadjib MDL, Delyuzar D. Ekspresi LMP1 pada Sel Tumor Sediaan Sitologi Biopsi Aspirasi Kelenjar Getah Bening Leher pada Metastasis Karsinoma Nasofaring. Majalah Patologi. 2015;24(2):39-46.

49. Sarac S, Akyol MU, Kanbur B, Poyraz A, Akyol G, Yilmaz T. Bcl-2 and LMP1 Expression in Nasopharyngeal Carcinomas. Am J Otolaryngol. 2001;22(6):377-382. https://doi.org/10.18632/oncotarget.4906

50. Nakanishi Y, Wakisaka N, Kondo S. Progression of Understanding for the Role of Epstein-Barr Virus and Management of Nasopharyngeal Carcinoma. Cancer Metastasis Rev. 2017;36(3):435-447. https://doi.org/10.1007/s10555-017-9693-x

51. Chow LWC, Khoo US, Yuen APW, and Wei WI. Expression of p53 in recurrent nodal metastasis from nasopharyngeal carcinoma (NPC). Eur J Surg Oncol. 1997;23(5):415-418. https://doi.org/10.1016/S07487983(97)93721-5 


\section{mutiara \\ medika}

52. Aswarin R, Yusuf M, and Wiyadi MS. Association of Protein Expression p53 Mutants with Regional Lymph Gland Status on type III Carcinoma Nasofaring Patients. Indian J Otolaryngol Head Neck Surg. 2018;70(3):405-409. https://doi.org/10.1007/s12070-018-1401-9

53. Sawali H, Yunus MR, Ai CO, and Athar SHPP. Cutaneous metastases from nasopharyngeal carcinoma : a rare manifestation. Philipp J Otolaryngol Head Neck Surg. 2010;25(2):32-35. https://doi.org/10.3860/pjohns.v25i2.1638

54. Shao JY, Ernberg I, Biberfeld P, Heiden T, Zeng YX, Hu LF. Epstein-Barr Virus LMP1 Status in Relation to Apoptosis , P53 Expression and Leucocyte Infiltration in Nasopharyngeal Carcinoma. Anticancer Res.2004;2318:2309-2318.

55. Chou J, Lin YC, Kim J, You L, Xu ZBHDMJ. Nasopharyngeal Carcinoma-Review of the Molecular Mechanisms of Tumorigenesis. Head Neck Nasopharyngeal. 2011;30(7):946-963. https://doi.org/10.1002/hed.20833

56. Lubis M. Kaitan apoptosis dengan ekspresi p-53 dan BCL-2 pada karsinoma nasofaring. Maj Patol Indones. 2002;11:46-51.

57. Yenita, Asri A. Korelasi antara Latent Membrane Protein-1 Virus Epstein-Barr dengan P53 pada Karsinoma Nasofaring (Penelitian Lanjutan). 2012;1(1):4-6. https://doi.org/10.25077/jka.v1i1.1 